\title{
Niejednoznaczne podstawy stosowania przepisów wymuszających swoje zastosowanie (przepisów koniecznego zastosowania)
}

\begin{abstract}
The article raises issues concerning legal basis for the application of the overriding mandatory rules. In the Polish doctrine there are two opposing concepts in terms of explanation of the legal grounds for application of overriding mandatory rules. Both theories do not have a universal dimension, in the sense that they do not sufficiently explain the basis for the application of domestic as well as foreign overriding mandatory rules, being part of lex causae or coming from a third state. The article presents arguments for and against the possibility of deriving the legal grounds for application of the overriding mandatory rules, with reference to submissions made to that effect in literature. The author makes also an attempt to formulate a concept complementary to the concept of an integrated conflict-of-law rule with the substantive law rule, boiling down to the assumption that the basis for application of overriding mandatory rule is a second degree conflict of laws rule allowing to apply a first degree conflict of laws rule integrated with the substantive rule.
\end{abstract}

Keywords: overriding mandatory rules, application of foreign law, law applicable, first and second degree conflict of laws rules.

a) Dr, Zakład Prawa Cywilnego i Prawa Międzynarodowego Prywatnego w Instytutcie Prawa Cywilnego Wydziału Prawa, Administracji i Ekonomii Uniwersytetu Wrocławskiego. 


\section{Zagadnienia wstępne}

\subsection{Przedmiot opracowania}

Przepisy wymuszające swoje zastosowanie, nazywane również przepisami koniecznego zastosowania, bezpośredniego zastosowania, czy też imperatywnymi w znaczeniu kolizyjnym, wywołują rozbieżności nie tylko na płaszczyźnie terminologicznej ${ }^{1}$, ale przede wszystkim w zakresie podstaw ich stosowania. W polskiej literaturze przedmiotu można spotkać dwa przeciwstawne stanowiska wyjaśniające podstawy stosowania przepisów wymuszających swoje zastosowanie. Pierwsze tzw. funkcjonalistyczne, zgodnie z którym przepisy wymuszające swoje zastosowanie zawieraja normy merytoryczne stosowane poza normalnym mechanizmem kolizyjnym ${ }^{2}$. Drugie zakładające, że konstrukcja przepisów wymuszajacych swoje zastosowanie polega na połaczeniu $\mathrm{w}$ ramach jednego przepisu normy merytorycznej, regulującej wprost daną sytuację życiową z jednostronna norma kolizyjną wyznaczajaca zakres zastosowania zintegrowanej z nią normy merytorycznej ${ }^{3}$. Oba stanowiska nie maja jednak uniwersalnego wymiaru $\mathrm{w}$ tym znaczeniu, że dostatecznie trafnie nie wyjaśniaja podstaw stosowania krajowych, jak i obcych przepisów wymuszajacych swoje zastosowanie, zarówno wchodzacych w skład lex causae, jak i pochodzących z państwa trzeciego.

W niniejszym opracowaniu zostana przedstawione argumenty przemawiające za, jak i przeciw możliwości wywodzenia podstaw stosowania przepisów wymuszajacych swoje zastosowanie $\mathrm{z}$ odwołaniem się do koncepcji prezentowanych w literaturze. Zostanie również podjęta próba sformułowania koncepcji komplementarnej względem koncepcji zintegrowanej jednostronnej normy kolizyjnej z normą merytoryczna, spro-

${ }^{1}$ M.A. Zachariasiewicz, w: Prawo prywatne międzynarodowe. Komentarz. Red. M. Pazdan. Warszawa 2018, s. 154.

${ }^{2}$ Zob. M. Mataczyński: Obce przepisy wymuszajace swoje zastosowanie. Rozważania na tle art. 7 ust. 1 Konwencji rzymskiej oraz orzecznictwa sqdów niemieckich. Kwartalnik Prawa Prywatnego [dalej: KPP] 2001, Nr 2, s. 377; Idem: Przepisy wymuszajace swoje zastosowanie $w$ prawie prywatnym międzynarodowym. Kraków 2005, s. 116 .

${ }^{3}$ A. Mączyński: Europejski kontekst rekodyfikacji polskiego prawa prywatnego międzynarodowego, w: „Finis legis Chrystus”. Księga pamiatkowa dedykowana księdzu profesorowi Wojciechowi Góralskiemu z okazji siedemdziesięciolecia rocznicy urodzin. Red. J. Krawczyński, J. Wroceński. T. 2. Warszawa 2009, s. 1188 i n.; M. Czepelak: Międzynarodowe prawo zobowiazań Unii Europejskiej. Wyd. 1. Warszawa 2012, s. 477. 
wadzającej się do przyjęcia, że podstawą stosowania przepisów wymuszajacych swoje zastosowanie jest zintegrowana z normą merytoryczna norma kolizyjna, stosowana jednak na podstawie normy kolizyjnej $\mathrm{II}^{\circ}$ obowiąującej w państwie forum.

\subsection{Przepisy wymuszające swoje zastosowanie}

W literaturze przedmiotu panuje zgoda co do tego, że pod pojęciem przepisów wymuszających swoje zastosowanie rozumie się przepisy zawierające normy o charakterze bezwzględnie obowiązującym (imperatywne) $)^{4}$. Omawiane przepisy zawieraja normy merytoryczne prawa wewnętrznego, które wprost regulują sytuacje życiowe z zakresu prawa prywatnego, łącząc określone konsekwencje prawne zawarte w ich dyspozycji z ujętym w sposób abstrakcyjny stanem faktycznym zawartym $\mathrm{w}$ ich hipotezie ${ }^{5}$. Podkreślić należy, że normy te nie rozstrzygają kolizji w przestrzeni pomiędzy systemami prawnymi różnych państw. Przepisy wymuszające swoje zastosowanie moga stanowić zarówno przepisy prawa publicznego, które odnoszą się wprost do danego prywatnoprawnego stosunku prawnego ${ }^{6}$, jak i przepisy prawa prywatnego ${ }^{7}$, o szczególnym jednak znaczeniu z punktów widzenia celów jakie mają realizować. Kluczowym elementem pozwalajacym na wyodrębnienie przepisów wymuszajacych swoje zastosowanie jest wola prawodawcy. Przejawia się ona w redakcji przepisu, z której musi wynikać, że przepis powinien być stosowany w celu realizacji określonych interesów państwowych lub organizacji międzynarodowych, niezależnie od tego, jakie prawo będzie właściwe dla sytuacji życiowej objętej jego zakresem zastosowania ${ }^{8}$.

Odnosząc się do celu, jaki mają realizować przepisy wymuszające swoje zastosowanie, należy wskazać na jego swoistą ewolucję. Początkowo przepisy wymuszające swoje zastosowanie służyły jedynie do ochrony interesów państwa w zakresie prawa prywatnego ${ }^{9}$. $\mathrm{Z}$ czasem jednak cel jakiemu maja służyć przepisy wymuszajace swo-

${ }^{4}$ Zob. M. Tomaszewski, w: Prawo prywatne międzynarodowe. Komentarz. Red. J. Poczobut. Warszawa 2017, s. 235.

${ }^{5}$ M. Czepelak: Międzynarodowe..., s. 477.

${ }^{6}$ Zob. więcej P. Rodziewicz: Stwierdzenie treści oraz zastosowanie prawa obcego w sqdowym postępowaniu cywilnym. Warszawa 2015, s. 180.

${ }^{7}$ G. Ż mij: Prawo waluty: Międzynarodowy obrót handlowy, prawo cywilne, prawo prywatne międzynarodowe, dochodzenie roszczeń w walutach obcych. Kraków 2003, s. 85 .

${ }^{8}$ M. Mataczyński: Przepisy..., s. 113.

${ }^{9}$ Zob. P. Rodziewicz: Stwierdzenie..., s. 180. 
je zastosowanie został poszerzony o ochronę interesów słabszych ekonomicznie stron stosunku prawnego, a więc interesów niezwiązanych $\mathrm{w}$ ścisłym tego słowa znaczeniu z interesami państwa ${ }^{10}$. Normatywna definicja przepisów wymuszajacych swoje zastosowanie została zawarta w przepisie art. 9 ust. 1 Rzym I ${ }^{11}$. Zgodnie z jego treścia, przepisy wymuszające swoje zastosowanie, to przepisy, których przestrzeganie uważane jest przez państwo za tak istotny element ochrony jego interesów publicznych, takich jak organizacja polityczna, społeczna lub gospodarcza, że znajduja one zastosowanie do stanów faktycznych objętych ich zakresem, bez względu na to, jakie prawo jest właściwe dla zobowiąania umownego. Oczywiście wskazana definicja odnosi się do przepisów wymuszających swoje zastosowanie, objętych zakresem zastosowania Rzym I, niemniej jednak z uwagi na jej uniwersalny charakter można ją odpowiednio odnieść, również do przepisów wymuszających swoje zastosowanie obejmujących swym zakresem inne sytuacje życiowe ${ }^{12}$. Przyjęta na gruncie Rzym I definicja nawiązuje do rozumienia przepisów wymuszajacych swoje zastosowanie wypracowanego przez Europejski Trybunał Sprawiedliwości (obecnie Trybunał Sprawiedliwości Unii Europejskiej [dalej: TSUE]) na gruncie orzeczenia zapadłego w sprawie Jean-Claude Arblade and Arblade \& Fils SARL13. W orzeczeniu tym TSUE przyją, że pod pojęciem przepisów dotyczących porządku publicznego należy rozumieć przepisy krajowe, których przestrzeganie jest tak kluczowe dla ochrony porządku politycznego, ekonomicznego i społecznego państwa członkowskiego, że powinny być przestrzegane przez wszystkie osoby znajdujące się na terytorium państwa członkowskiego oraz powinny być stosowane do wszystkich stosunków prawnych w ramach tego państwa ${ }^{14}$.

${ }^{10}$ J.J. Kuipers: EU Law and Private International Law: The Interrelationship in Contractual Obligations. Lejda 2012, s. 61.

${ }^{11}$ Rozporządzenie Parlamentu Europejskiego i Rady (WE) nr 593/2008 z dnia 17 czerwca 2008 r. w sprawie prawa właściwego dla zobowiązań umownych (Rzym I). Dz.U. L 177 z 4.07.2008, s. 6-16 [dalej: Rzym I].

${ }^{12}$ M. Glicz: Przepisy wymuszajace swoje zastosowanie $w$ międzynarodowym obrocie papierami wartościowymi. Gdańskie Studia Prawnicze [dalej: GSP]. Tom XXXVI. 2016, s. 151.

${ }^{13}$ Wyrok Trybunału z dnia 23.11.1999 r. w połączonych sprawach Jean-Claude Arblade i Arblade \& Fils SARL (C-369/96) i Bernard Leloup, Serge Leloup i Sofrage SARL (C-376/96). ECLI:EU:C:1999:575.

${ }^{14}$ Ibidem. 


\subsection{Rodzaje przepisów wymuszających swoje zastosowanie}

Przepisy wymuszające swoje zastosowanie nie mają jednorodnego charakteru, w konsekwencji można wyróżnić kilka grup przepisów wymuszających swoje zastosowanie, a także kilka kryteriów wykorzystywanych na potrzeby ich klasyfikacji ${ }^{15}$. Z punktu widzenia niniejszego opracowania najistotniejsze znaczenie ma podział na krajowe oraz obce przepisy wymuszające swoje zastosowanie ${ }^{16}$. Podążając za terminologia przyjęta przez M. Mataczyńskiego, mianem krajowych przepisów wymuszających swoje zastosowanie określa się przepisy, które należą do systemu prawnego państwa, w którym sąd orzekający ma swoją siedzibę (przepisy wchodzace w skład lex fori $)^{17}$. Natomiast pod pojęciem obcych przepisów wymuszających swoje zastosowanie, wskazany Autor rozumie przepisy wymuszajace swoje zastosowanie należacce do innych - obcych - systemów prawnych, przy czym wskazuje, że chodzi tu o przepisy niebędace ani przepisami lex fori, ani prawa właściwego dla danego stosunku prawnego (lex causae) wskazanego za pomoca miarodajnej normy kolizyjnej ${ }^{18}$. Przepisy te można określić, jako przepisy państwa trzeciego, które pozostają w ścisłym związku z danym stanem faktycznym ${ }^{19}$. Oczywiście wskazana typologia zasługuje na aprobatę, niemniej jednak na potrzeby rozważań prowadzonych w dalszej części niniejszego opracowania pod pojęciem obcych przepisów wymuszających swoje zastosowanie będę rozumiał przepisy państwa trzeciego pozostajace $\mathrm{w}$ związku z danym stanem faktycznym, które będę nazywał obcymi przepisami wymuszającymi swoje zastosowanie sensu stricto, które wraz z obcymi przepisami wymuszającymi swoje zastosowanie wchodzacymi w skład lex causae, składać się będą na obce przepisy wymuszające swoje zastosowanie sensu largo. Wprowadzenie takiego rozróżnienia uzasadniam tym, że inna może być podstawa zastosowania obu wskazanych grup przepisów, co stanowić będzie zasadniczy przedmiot rozważań w dalszych częściach niniejszego opracowania.

${ }^{15}$ Zob. M.A. Zachariasiewicz, w: „System Prawa Prywatnego”. T. 20A: Prawo prywatne międzynarodowe. Red. M. Pazdan. Warszawa 2014, s. 451.

${ }^{16}$ M. Mataczyński: Przepisy..., s. 50 i n.

${ }^{17}$ Ibidem, s. 50.

${ }^{18}$ Ibidem.

${ }^{19}$ Ibidem, s. 51. 


\subsection{Zastosowanie versus uwzględnienie przepisów wymuszających swoje zastosowanie}

W literaturze przedmiotu wyraźnie odróżnia się zastosowanie od uwzględnienia przepisów wymuszających swoje zastosowanie ${ }^{20}$. Również w orzecznictwie TSUE wyraźnie zwrócono uwagę na wskazaną dystynkcję ${ }^{21}$. Zastosowanie przepisów wymuszających swoje zastosowanie polega na bezpośrednim powiązaniu skutków prawnych wynikających z ich dyspozycji z ustalonym stanem faktycznym objętym zakresem przepisu wymuszajacego swoje zastosowanie ${ }^{22}$. W razie zastosowania przepisu wymuszającego swoje zastosowanie, stanowi on podstawę prawna rozstrzygnięcia $\mathrm{w}$ procesie stosowania prawa. Uwzględnienie przepisów wymuszajacych swoje zastosowanie polega natomiast na wzięciu wskazanych przepisów pod uwage jedynie jako elementu stanu faktycznego określonej sytuacji życiowej, co może się wiązać, z powiązaniem z tak ustalonym stanem faktycznym odmiennych konsekwencji prawnych wynikających z dyspozycji prawa właściwego (wskazanego na podstawie miarodajnej normy kolizyjnej), aniżeli w sytuacji, w której przepis wymuszajaccy swoje zastosowanie nie zostałby wzięty pod uwagę. W przypadku uwzględnienia przepisu wymuszającego swoje zastosowanie konsekwencje prawne ustalonego stanu faktycznego wprost sa kształtowane przez zakresy normowania przepisów prawa właściwego, na których zastosowanie jedynie pośrednio może mieć wpływ uwzględnienie przepisów wymuszających swoje zastosowanie. Tytułem przykładu można wskazać na orzeczenie angielskiego Court of Appeal w sprawie Ralli Bros v Cia Naviera Sota y Aznar23. Sąd we wskazanej sprawie oddalił roszczenie o zapłatę kwoty, przewyższającej stawkę maksymalną przewidzianą w hiszpańskim przepisie wymuszajacym swoje zastosowanie na podstawie przepisów lex causae (którym było prawo angielskie), zgodnie

${ }^{20}$ Zob. M. Wojewoda: Problematyka kolizyjnoprawna umów o roboty budowalne. W: Europejskie prawo procesowe cywilne i kolizyjne. Red. P. Grzegorczyk, K. Weitz. Wyd. 1. Warszawa 2012, s. 503; A. Kronenberg: Foreign overriding mandatory provisions under the Regulation (EC) No 593/2008 (Rome I Regulation). Judgment of the European Court of Justice of 18 October 2016, case C-135/15. Cuadernos de Derecho Transnacional. Vol. 11. No 1 (2019), s. 879 - DOI: https://doi.org/10.20318/cdt.2018.4409. Zob. G. Kegel: Chapter 3. Fundamental Approaches. W: International Encyclopedia of Comparative Law. Private International Law. Volume III. Red. K. Lipstein. Tybinga 1986, s. 35 .

${ }^{21}$ Wyrok Trybunału z dnia 18.10.2016 r. w sprawie Republika Grecko przeciwko Grigoris Nikiforidis (C - 135/15). ECLI:EU:C:2016:774.

${ }^{22}$ Por. M. Tomaszewski, w: Prawo..., s. 238.

${ }^{23}$ Court of Appeal w sprawie Ralli Brothers $v$. Compania Naviera Sota y Aznar (1920) 2 Ll.L.Rep. 550. 
z którymi nie można udzielić ochrony prawnej roszczeniu wynikającemu $\mathrm{z}$ umowy w sytuacji, gdy spełnienie świadczenia z niej wynikajacego jest zakazane zgodnie z prawem miejsca wykonania umowy ${ }^{24}$. W tym przypadku obce przepisy wymuszajace swoje zastosowanie nie zostały zastosowane per se, ale jedynie podlegały uwzględnieniu jako element stanu faktycznego powodujacy jednocześnie sięgnięcie do właściwych przepisów lex causae ${ }^{25}$. Podkreślić przy tym należy, że stosowanie określonych grup przepisów wchodzacych w skład prawa obcego (których stosowanie nie opiera się na obowiazywaniu w systemie prawnym forum) zależy od istnienia podstawy prawnej na to zezwalajaccej. W przypadku uwzględnienia danego przepisu jako elementu faktycznego nie jest potrzebna natomiast wyraźna podstawa prawna (wynikająca z przepisów prawa prywatnego międzynarodowego), aby móc przyznać mu skuteczność, z tym zastrzeżeniem, że przyznanie skuteczności nie powoduje, że dany przepis staje się podstawa prawną rozstrzygnięcia, a jedynie brany jest pod uwagę jako element stanu faktycznego określonej sytuacji życiowej (sprawy). Wskazana konkluzja znajduje potwierdzenie w wyroku TSUE w sprawie C-135/15 Republika Grecka przeciwko Grigoris Nikiforidis ${ }^{26}$. TSUE wyraził bowiem pogląd, że nic nie stoi na przeszkodzie, aby inne przepisy wymuszajace swoje zastosowanie niż przepisu państwa wykonania zobowiązania mogły zostać uwzględnione, jako element stanu faktycznego, pomimo tego, że brak jest do tego wyraźnej podstawy prawnej, która wynikałaby z przepisu art. 9 ust. 3 Rzym I ${ }^{27}$.

\section{Podstawy stosowania przepisów wymuszających swoje zastosowanie}

W polskiej literaturze przedmiotu istnieja dwa przeciwstawne stanowiska wyjaśniające podstawę stosowania przepisów wymuszających swoje zastosowanie. Stanowisko funkcjonalistyczne, zakładające, że przepisy wymuszające swoje zastosowanie zawieraja normy stosowane poza normalnym mechanizmem kolizyjnym ${ }^{28}$. Oznacza to, że podmiot

${ }^{24}$ P. Nygh: Autonomy in International Contracts. Oxford 1999, s. 224.

${ }^{25}$ Ibidem, s. 224.

${ }^{26}$ Wyrok Trybunału z dnia 18.10.2016 r. w sprawie Republika Grecko przeciwko Grigoris Nikiforidis (C - 135/15). ECLI:EU:C:2016:774.

${ }^{27}$ Ibidem.

${ }^{28}$ M. Mataczyński: Obce..., s. 377. 
stosujący prawo powinien dokonać analizy funkcjonalnej określonego przepisu i jeśli jej efekty wskazują na szczególne cele, jakie są związane z przyjęciem danego przepisu, możliwe jest jego zastosowanie niezależnie od wskazania prawa właściwego przez miarodajną normę kolizyjną ${ }^{29}$. W myśl założeń przedstawionej koncepcji trafnie się przyjmuje, że przepisy wymuszajace swoje zastosowanie same wyznaczaja zakres swojego stosowania $^{30}$. Odmienna koncepcja zakłada, że konstrukcja przepisów wymuszających swoje zastosowanie polega na połączeniu w ramach jednego przepisu normy merytorycznej, regulującej wprost daną sytuację życiowa, z jednostronną normą kolizyjną wyznaczająca zakres zastosowania zintegrowanej z nia normy merytorycznej, gdzie wskazana jednostronna norma kolizyjna stanowi lex specialis w stosunku do zupełnej normy kolizyjnej miarodajnej dla danej sytuacji życiowej ${ }^{31}$. W ramach tej koncepcji można mówić o tzw. ukrytej normie kolizyjnej, zgodnie z którą podstawą stosowania określonego prawa (przepisu) jest zawsze norma kolizyjna ${ }^{32}$. Druga z przedstawionych koncepcji spotkała się ze zdecydowana krytyką w doktrynie. W szczególności sceptycznie odnieśli się do niej M. Mataczyński $i^{33}$ i M.A. Zachariasiewicz ${ }^{34}$. Zgodzić należy się z krytyką wyrażona przez wskazanych Autorów, której ostrze skierowane było w odniesieniu do stosowania krajowych przepisów wymuszających swoje zastosowanie. Albowiem podstawą stosowania krajowych przepisów wymuszajacych swoje zastosowanie nie jest ukryta norma kolizyjna, ale funkcja i cel tych przepisów, a także fakt ich obowiązywania w systemie prawnym sądu orzekajacego ${ }^{35}$. Przy odrzuceniu koncepcji uniwersalistycznej zakresu zastosowania prawa prywatnego międzynarodowego ${ }^{36}$ i przy przyjęciu trafnego założenia sformułowanego w literaturze ${ }^{37}$, o domniemaniu kompetencji polskiego prawa materialnego $\mathrm{w}$ zakresie ju-

${ }^{29}$ Por. M.A. Zachariasiewicz, w: Prawo..., s. 468.

${ }^{30}$ M. Mataczyński: Przepisy..., s. 116.

${ }^{31}$ A. Mączyński: Europejski..., s. 1188 i n.; M. Czepelak: Międzynarodowe..., s. 477.

${ }^{32}$ M. Mataczyński: Przepisy..., s. 114 i n.

${ }^{33}$ Ibidem, s. 113 i n.

${ }^{34}$ M.A. Zachariasiewicz: O potrzebie wskazania $w$ nowej ustawie o prawie prywatnym międzynarodowym podstawy stosowania przepisów wymuszajacych swoje zastosowanie. Problemy Prawa Prywatnego Międzynarodowego [dalej: PPPM]. T. 7. Red. M. Pazdan. Katowice 2010, s. 42.

${ }^{35}$ M. Mataczyński: Przepisy..., s. 113 i n.

${ }^{36}$ Zob. więcej M. Pazdan, w: „System Prawa Prywatnego”. T. 20A: Prawo prywatne międzynarodowe. Red. M. Pazdan. Warszawa 2014, s. 17.

${ }^{37}$ Zob. H. Kelsen: Principles of International Law. Wyd. oryg. 1952. Reprint New Jersey 2003, s. 254. 
rysdykcji państwa polskiego ${ }^{38}$, należy dojść do wniosku, że właściwość obcego prawa będzie wyłączać stosowanie prawa polskiego jako lex fori. Pośrednio do takiego wniosku prowadzi redakcja przepisu art. 8 ust. 1 p.p.m. ${ }^{39}$, zgodnie z którym wskazanie prawa właściwego nie wyłącza zastosowania tych przepisów prawa polskiego, z których treści lub celów wynika, że regulują one podlegajacy ocenie stosunek prawny, bez względu na to, jakiemu prawu on podlega. $\mathrm{Z}$ treści omawianego przepisu można wywnioskować, że norma kolizyjna, jeśli tylko jako prawo właściwe wskaże prawo obce, wyłącza ona możliwość stosowania przepisów prawa polskiego, z wyjątkiem krajowych przepisów wymuszających swoje zastosowanie. Mając powyższe na uwadze, należy dojść do wniosku, że w zakresie stosowania krajowych przepisów wymuszających swoje zastosowanie na aprobatę zasługuje pogląd $M$. Mataczyńskiego, podzielony przez M.A. Zachariasiewicz, że przepisy wymuszajace swoje zastosowanie same wyznaczaja zakres swojego stosowania ${ }^{40}$, co jedynie podkreśla przepis art. 8 ust. 1 p.p.m. Jednakże powyższe stanowisko nie może zostać zaadaptowane do obcych przepisów wymuszających swoje zastosowanie $^{41}$. O ile stosowanie krajowych przepisów wymuszających swoje zastosowanie może być uzasadnione faktem ich obowiązywania w systemie prawnym państwa forum, o tyle nie ma przekonujacego uzasadnienia dla stosowania obcych przepisów wymuszających swoje zastosowanie bez odwołania się do normy kolizyjnej. Antycypując argumenty odnoszące się do budowy systemu prawnego, podzielić należy pogląd wyrażony przez H. Kelsena, że podstawa stosowania przepisów pochodzacych z obcego systemu prawnego może być wyłącznie właściwa norma kolizyjna prawa prywatnego międzynarodowego ${ }^{42}$.

Majac na uwadze zasygnalizowany podział na przepisy wymuszające swoje zastosowanie wchodzace $\mathrm{w}$ skład lex causae oraz przepisy wymuszajace swoje zastosowanie sensu stricto pochodzace z państwa trzeciego, uznać należy, że inne będa podstawy stosowania każdej ze wskazanych grup przepisów. Kwestią niebudząca większych wątpliwości jest możliwość zastosowania przez polski sąd obcych przepisów wymuszających

${ }^{38}$ M. Mataczyński: Przepisy..., s. 114; Przeciwko istnieniu takiego domniemania wyraźnie wypowiada się m.in. M. Pazdan: Prawo prywatne międzynarodowe. Wyd. 15. Warszawa 2012, s. 82.

${ }^{39}$ Ustawa z dnia 04.02.2011 r. - Prawo prywatne międzynarodowe. Dz.U. 2015 r. Poz. 1792 t.j. [dalej: p.p.m.]

${ }^{40}$ Por. M. Mataczyński: Przepisy..., s. 116.

${ }^{41}$ Zob. A. Bonomi: Mandatory Rules in Private International Law - The Quest for Uniformity of Decisions in a Global Environment. Yearbook of Private International Law [dalej: YPIL]. Vol. 1 (1999). Red. P. Šarčević, P. Volken. Monachium 1999, s. 234.

${ }^{42}$ Zob. H. Kelsen: Principles..., s. 254. 
swoje zastosowanie, które wchodzą w skład lex causae ${ }^{43}$ nawet wówczas, gdy sa to przepisy o charakterze publicznoprawnym ${ }^{44}$, z tym jednak zastrzeżeniem, że spełnione sa kryteria ich stosowania przewidziane $e x$ plicite $\mathrm{w}$ art. 6 ust. 1 p.p.m. Upoważnienie do stosowania omawianych obcych przepisów prawa publicznego wymuszających swoje zastosowanie następować będzie $\mathrm{w}$ oparciu o przepis art. 6 ust. 1 p.p.m. w związku z przepisem zawierajacym normę kolizyjną wskazująca prawo właściwe dla określonej sytuacji życiowej ${ }^{45}$. Zauważmy jednocześnie, w nawiąaniu do wcześniejszych rozważań, że skoro przepisy te w państwie, z którego pochodza, są stosowane zawsze, tym samym spełniony będzie warunek ich stosowania wyrażony explicite $\mathrm{w}$ treści przepisu art. 6 ust. 1 p.p.m. ${ }^{46}$ Co jednak istotne, będą one stosowane nawet wówczas, gdy nie będą to przepisy wymuszajace swoje zastosowanie tak zwanej drugiej generacji, ale przepisy zmierzajace do ochrony partykularnych interesów państwa, z którego pochodza, w zakresie prawa prywatnego ${ }^{47}$. Zważywszy na to, uzasadniony jest postulat, aby sąd przed przystapieniem do stosowania tego typu przepisów prawa obcego antycypował ewentualne skutki ich zastosowania $\mathrm{w}$ kontekście sprzeczności z podstawowymi zasadami porządku prawnego, co może stanowić uzasadnioną przyczynę przemawiająca za sięgnięciem po klauzulę porządku publicznego i odmową ich zastosowania. Dokonując analizy podstawy stosowania obcych przepisów wymuszających swoje zastosowanie wchodzacych w skład lex causae, należy zauważyć, że podstawą ich stosowania jest nakaz zawarty w obowiazującej w siedzibie sądu normie kolizyjnej, która wskazuje prawo określonego państwa, jako właściwe dla danej sytuacji życiowej, względnie obca norma kolizyjna wskazująca prawo właściwe, co znajduje uzasadnienie w normie kolizyjnej $\mathrm{II}^{\mathrm{o}}$ państwa forum (np. instytucja odesłania). Wskazanie to obejmuje nie poszczególne przepisy, ale porządek określonego państwa jako całość ${ }^{48}$. Dlatego należy przyjąć, że obejmuje ono również obce przepisy wymuszajace swoje zastosowanie wchodzace w skład lex causae $^{49}$. W literaturze obcej można spotkać się z poglądami kwestionującymi możliwość automatycznego stosowania obcych przepisów wymu-

${ }^{43}$ Zob. G. Żmij: Prawo..., s. 98.

${ }^{44}$ Zob. B. Fuchs: Statut..., s. 73.

${ }^{45}$ Zob. P. Rodziewicz: Prawo prywatne oraz prawo publiczne z perspektywy prawa prywatnego międzynarodowego. Studia Prawa Prywatnego [dalej: SPP]. Nr 3 2017, s. 9.

${ }^{46}$ Por. ibidem, s. 9.

${ }^{47}$ J.J. Kuipers: EU Law..., s. 61.

${ }^{48}$ W. Ludwiczak: Międzynarodowe prawo prywatne. Wyd. 3. zmienione. Warszawa 1961, s. 14.

${ }^{49}$ Por. J.J. Kuipers: EU Law..., s. 148. 
szających swoje zastosowanie wchodzących $\mathrm{w}$ skład lex causae $e^{50}$. Takie poglądy nie zasługuja na aprobatę w świetle przepisów polskiej p.p.m., zgodnie z którą możliwość uwzględniania obcych przepisów wymuszajacych swoje zastosowanie przewidziana w art. 8 ust. 2 p.p.m. dotyczy jedynie przepisów pochodzacych z państwa trzeciego z punktu widzenia lex causae. Tym samym należy przyjać, że w przypadku przepisów wymuszających swoje zastosowanie wchodzących w skład lex causae podstawa ich stosowania jest miarodajna dla określonej sytuacji życiowej norma kolizyjna.

Należy jednak zwrócić uwagę na jedna zasadniczą kwestię. Prawo właściwe zostaje wskazane na podstawie normy kolizyjnej dla określonej sytuacji życiowej mieszczącej się w ramach danego statutu, w związku z tym pojawia się pytanie, co w sytuacji, gdy obce przepisy wymuszajace swoje zastosowanie nie mieszczą się w granicach statutu, dla którego prawo właściwe zostało wskazane. Czy wówczas stosowane miałyby być obce przepisy wymuszajace swoje zastosowanie wchodzace w skład lex causae, które mieszczą się w granicach statutu dla określonej sytuacji życiowej, czy może powinny być stosowane również przepisy wykraczające poza zakres statutu? Powyższy problem wydaje się być jednak pozorny, skoro funkcja i cel przepisów wymuszających swoje zastosowanie będzie miała decydujące znaczenie, w zakresie tego, czy przepisy te powinny być stosowane jako część lex causae. Odpowiedź na tak zadane pytanie jest udzielana w ramach tzw. kwalifikacji wtórnej dokonywanej na etapie stosowania lex cause (prawa obcego) ${ }^{51}$.

Dokonując czastkowego podsumowania, podstawa normatywna stosowania przepisów wymuszających swoje zastosowanie wchodzących w skład lex causae jest norma kolizyjna wskazujaca prawo właściwe dla ocenianej sytuacji życiowej. W związku z tym, o ile zastosowanie krajowych przepisów wymuszających swoje zastosowanie poza mechanizmem kolizyjnoprawnym wydaje się być uzasadnione, o tyle zastosowanie obcych przepisów wymuszajacych swoje zastosowanie wchodzacych w skład lex causae następuje na podstawie mechanizmu kolizyjnoprawnego. Należy przy tym zauważyć, że nie sa one stosowane na podstawie ukrytej normy kolizyjnej zawartej w obcym przepisie ${ }^{52}$. Idac bowiem tym tokiem rozumowania określone przepisy wchodzace w skład lex causae byłyby wskazywane jako właściwe za pomocą obcej normy kolizyjnej. Należy

${ }^{50}$ K. Boele-Woelki, D. van Iterson: The Dutch Private International Law Codification: Principles, Objectives and Opportunities. Electronic Journal of Comparative Law [dalej: EJCL]. Vol. 14.3. December 2010. http://www.ejcl.org/143/art143-3.pdf [dostęp: 15.01.2020 r. ], s. 9.

${ }^{51}$ Por. P. Rodziewicz: Stwierdzenie..., s. 226.

${ }^{52}$ Odmiennie zob. A. Mączyński: Europejski..., s. 1188. 
przy tym pamiętać, że tylko w przypadkach wprost przewidzianych przez normę kolizyjną $\mathrm{II}^{\circ}$, obowiązujacca w siedzibie organu stosującego prawo, dopuszczalne jest stosowanie obcych norm kolizyjnych $\mathrm{I}^{\mathrm{053}}$. Analiza założeń omawianej koncepcji prowadzi do wniosku, że obca jednostronna norma kolizyjna zintegrowana $\mathrm{w}$ ramach przepisu wymuszajacego swoje zastosowanie z normą merytoryczna stanowić miałaby lex specialis względem krajowej zupełnej normy kolizyjnej54. Takie założenie jest niedopuszczalne. Reguły inferencyjne rozstrzygajace kolizję norm opartą na relacji lex specialis - lex generalis moga być stosowane do rozstrzygania kolizji norm w ramach jednego systemu prawnego ${ }^{55}$, w tym przypadku powstaje natomiast kolizja między normami kolizyjnymi $I^{\circ}$ pochodzacymi z różnych państw (różnych systemów prawnych), która może być rozstrzygana tylko i wyłącznie w oparciu o miarodajne normy kolizyjne $\mathrm{II}^{\circ}$. W konsekwencji wysoce problematyczna pozostaje kwestia możliwości zastosowania obcych przepisów wymuszających swoje zastosowanie niewchodzacych $\mathrm{w}$ skład lex causae. O ile w przypadku obcych przepisów wymuszajacych swoje zastosowanie wchodzacych w skład lex causae podstawą stosowania przepisów wymuszających swoje zastosowanie jest nakaz zawarty we właściwej normie kolizyjnej obowiąującej w siedzibie sadu oraz ewentualna treść tych przepisów, z której wynika konieczność ich stosowania, o tyle w przypadku przepisów wymuszających swoje zastosowanie pochodzących z państwa trzeciego takiej podstawy brak.

Mając powyższe na uwadze, żadna z przedstawionych koncepcji nie stanowi podstawy dostatecznie uzasadniającej możliwość stosowania obcych przepisów wymuszających swoje zastosowanie sensu stricto.

\section{Koncepcja komplementarna względem zintegrowanej normy kolizyjnej z normą prawa merytorycznego}

W doktrynie prawa prywatnego międzynarodowego powszechnie akceptowany jest podział norm kolizyjnych na normy kolizyjne $\mathrm{I}^{\mathrm{o}} \mathrm{i}_{\mathrm{II}}^{\mathrm{0} 56}$. Normy kolizyjne $\mathrm{I}^{\mathrm{o}}$ rozgraniczaja sfery działania norm merytorycznych, które należą do systemów prawnych obowiązujących w różnych pań-

${ }^{53}$ Zob. i por. M. Pazdan: Prawo..., s. 66.

${ }^{54}$ Zob. A. Mączyński: Europejski..., s. 1188 i n.

${ }^{55}$ Zob. W. Lang, J. Wróblewski, S. Zawadzki: Teoria państwa i prawa. Wyd. 3. Warszawa 1986, s. 403.

${ }^{56}$ Zob. M. Pazdan, w: Prawo..., s. 199. 
stwach, natomiast normy kolizyjne $\mathrm{II}^{\mathrm{o}}$ rozgraniczają sfery działania norm kolizyjnych $\mathrm{I}^{\mathrm{o}}$ wchodzacych $\mathrm{w}$ skład systemów prawnych różnych państw ${ }^{57}$. Zgodnie z akceptowanym poglądem doktryny organy określonego państwa, co do zasady stosują normy kolizyjne $\mathrm{I}^{\circ}$, które obowiązuja $\mathrm{w}$ ich siedzibie, chyba że norma kolizyjna $\mathrm{II}^{\circ}$ zezwala na zastosowanie obcych norm kolizyjnych $\mathrm{I}^{058}$. Mając powyższe na uwadze, należy podkreślić, że obce normy kolizyjne moga być stosowane jedynie wtedy, gdy znajduje to podstawę $\mathrm{w}$ dyspozycji normy kolizyjnej $\mathrm{II}^{\circ}$ obowiąujaccej $\mathrm{w}$ siedzibie danego organu stosującego prawo $^{59}$. Zgodnie z założeniami koncepcji zintegrowanej normy kolizyjnej z jednostronną normą kolizyjną podstawą stosowania przepisów wymuszajacych swoje zastosowanie jest jednostronna norma kolizyjna I'. Słabość wskazanej koncepcji ujawnia się w przypadku, gdy zastosowany ma zostać przepis wymuszający swoje zastosowanie pochodzaccy z państwa trzeciego, albowiem dopuszcza ona możliwość stosowania obcej jednostronnej normy kolizyjnej $\mathrm{I}^{\mathrm{o}} \mathrm{z}$ pominięciem wskazanych założeń, związanych z obowiązywaniem normy kolizyjnej $\mathrm{II}^{\circ}$ zezwalającej na zastosowanie zintegrowanej jednostronnej normy kolizyjnej. Komplementarność przedstawionej w niniejszym opracowaniu koncepcji polega na przyjęciu, jako podstawy stosowania obcych przepisów wymuszających swoje zastosowanie, koncepcji zintegrowanej normy kolizyjnej z tym zastrzeżenie, że podstawa jej zastosowania jest norma kolizyjna $\mathrm{II}^{\mathrm{o}}$, obowiąująca w państwie forum, której rekonstrukcji zostaną poświęcone dalsze rozważania.

$\mathrm{W}$ obowiązującym $\mathrm{w}$ Polsce stanie prawnym istnieją trzy podstawy normatywne, które wymagają rozważenia w kontekście rekonstrukcji normy kolizyjnej $\mathrm{II}^{\circ}$ pozwalajacej na stosowanie obcych przepisów wymuszających swoje zastosowanie, a mianowicie przepis art. 8 ust. 2 p.p.m., art. 9 ust. 3 Rzym I oraz art. 30 Rozporządzenia spadkowego ${ }^{60}$. Każdy z przywołanych przepisów swym zakresem obejmuje szczególnego rodzaju przepisy o charakterze imperatywnym, zawierając w swej dyspozycji wskazanie w jaki sposób powinna zostać przyznana im skuteczność. Jak jednak wskazano na wstępie niniejszego artykułu, przyznanie skuteczności przepisom wymuszającym swoje zastosowanie może przybie-

${ }^{57}$ Por. K. Przybyłowski: $Z$ problematyki stosowania obcych norm kolizyjnych. Ustawowe uregulowanie uwzględniania obcych norm kolizyjnych w polskim prawie międzynarodowym prywatnym. Kraków 1959, s. 5.

${ }^{58}$ Zob. i por. P. Rodziewicz: Stwierdzenie..., s. 155 i n.

${ }^{59}$ Por. ibidem, s. 155 i n.

${ }^{60}$ Rozporządzenie Parlamentu Europejskiego i Rady (UE) nr 650/2012 z dnia 4 lipca 2012 r. w sprawie jurysdykcji, prawa właściwego, uznawania i wykonywania orzeczeń, przyjmowania i wykonywania dokumentów urzędowych dotyczących dziedziczenia oraz w sprawie ustanowienia europejskiego poświadczenia spadkowego (dalej: rozporządzenie spadkowe). 
rać dwojaka postać, a mianowicie może polegać na ich stosowaniu lub uwzględnieniu. Norma kolizyjna zasadniczo rozstrzyga jakie prawo lub jaka norma kolizyjna ma zostać zastosowana, a nie uwzględniona, dlatego też normy kolizyjnej $\mathrm{II}^{\mathrm{o}}$ można się doszukiwać w ramach wskazanych przepisów tylko w takim zakresie, w jakim pozwalaja one na stosowanie przepisów wymuszajacych swoje zastosowanie. Przechodząc do analizy przywołanych przepisów, rozstrzygnąc należy, czy uwzględnienie przepisów wymuszających swoje zastosowanie na gruncie przepisu art. 8 ust. 2 p.p.m. oraz przyznanie skuteczności przepisom wymuszającym swoje zastosowanie na gruncie przepisu art. 9 ust. 3 Rzym I jest tożsame ze stosowaniem wskazanych przepisów, rozumianym jako przyjęcie ich za podstawę prawną rozstrzygnięcia ${ }^{61}$, co pozwoliłoby na rekonstrukcje na podstawie wskazanych przepisów normy kolizyjnej $\mathrm{II}^{\circ}$ pozwalającej na stosowanie obcych przepisów wymuszających swoje zastosowanie. W dalszym miejscu zostanie poddany analizie również przepis art. 30 rozporządzenia spadkowego.

W polskiej literaturze wskazuje się na istniejące wątpliwości, co do sposobu, w jaki ma być przyznany skutek obcym przepisom wymuszającym swoje zastosowanie, pochodzącym z państwa trzeciego ${ }^{62}$. Kontrowersje wynikaja z tego, że według niektórych poglądów przyznanie skutku nie obejmuje stosowania, a jedynie uwzględnienie jako okoliczność faktyczna ${ }^{63}$. W odniesieniu do powyższego $W$. Popiołek wskazuje, że raczej za nietrafne należy uznać poglądy wskazujące, że przyznanie skutku nie obejmuje zastosowania ${ }^{64}$. Autor ten analogicznie przyjmuje, że „przyznanie skutku” obcym przepisom wymuszajacym swoje zastosowanie na gruncie przepisów Rzymu I oznacza zarówno ich stosowanie, jak i uwzględnienie ${ }^{65}$. Wydaje się, że w podobnym tonie w odniesieniu do przepisu art. 9 ust. 3 Rzym I wypowiada się M.A. Zachariasiewicz, która wskazuje, że obce przepisy wymuszające swoje zastosowanie, nieobjęte zakresem wskazanego przepisu, mogą zostać uwzględnione jako element stanu faktycznego ocenianego w świetle prawa właściwego, a contrario obce przepisy wymuszające swoje zastosowanie mieszczace się w zakresie wskazanego przepisu rozporządzenia, czyli lex loci solutionis, będą

${ }^{61}$ Zob. M. Bogdan: Private International Law as Component of the Law of the Forum. General Course. Haga 2012, s. 250.

${ }^{62}$ W. Popiołek: Wykonanie zobowiazania umownego a prawo miejsca wykonania. Zagadnienia kolizyjnoprawne. Katowice 1989, s. 73.

${ }^{63}$ Ibidem, s. 73.

${ }^{64}$ Ibidem, s. 74.

${ }^{65}$ Zob. W. Popiołek: Prawo wtaściwe dla umownych zobowiazań elektronicznych $w$ konwencji rzymskiej i projekcie rozporzqdzenia Rzym I. W: Kolizyjne aspekty zobowiazań elektronicznych. Materiały z konferencji. Red. J. Gołaczyński. Warszawa 2008, s. 27. 
mogły zostać zastosowane ${ }^{66}$. Analogicznie możliwość stosowania obcego przepisu wymuszajacego swoje zastosowanie na podstawie przepisu art. 7 ust. 1 Konwencji rzymskiej dopuszczała B. Fuch $s^{67}$. Autorka ta jednak w nowszych publikacjach prezentuje stanowisko, zgodnie z którym obce przepisy wymuszajace swoje zastosowanie powinny podlegać jedynie uwzględnieniu jako element stanu faktycznego ${ }^{68}$. W literaturze reprezentowany jest również pogląd odnoszący się do przepisu art. 9 ust. 3 Rzym I, w myśl którego uwzględnienie lex loci solutionis samo w sobie nie oznacza możliwości stosowania obcych przepisów wymuszających swoje zastosowanie $^{69}$. Mając jednak na uwadze wyrok TSUE w sprawie C - 135/15 Republika Grecka przeciwko Grigoris Nikifori$\operatorname{dis}^{70}$, na aprobatę zasługuja przytoczone wyżej poglądy, zgodnie z którymi przepis art. 9 ust. 3 Rzym I interpretować należy w ten sposób, że przyznanie skuteczności przepisom państwa, w którym nastąiło lub ma nastapić wykonanie zobowiązania, polega na możliwości ich zastosowania. W konsekwencji w oparciu o przepis art. 9 ust. 3 Rzym I możliwe jest zrekonstruowanie normy kolizyjnej $\mathrm{II}^{\circ}$, której dyspozycja zezwala na stosowanie przepisów wymuszających swoje zastosowanie państwa miejsca wykonania zobowiązania. Jeśli tylko w państwie miejsca wykonania zobowiazania obowiąuje przepis wymuszajacy swoje zastosowanie, który zawiera zintegrowaną jednostronną normę kolizyjną z normą merytoryczna, to przepis art. 9 ust. 3 Rzym I, zezwala na zastosowanie wskazanej jednostronnej normy kolizyjnej. W konsekwencji przyznanie skuteczności, czyli zastosowanie zintegrowanej z nim normy merytorycznej.

Przechodząc do analizy przepisu art. 8 ust. 2 p.p.m., należy mieć na uwadze, że konsekwentnie ustawodawca posługuje się w nim terminem uwzględnienie w odniesieniu do obcych przepisów wymuszajacych swoje zastosowanie, podczas gdy w przepisie art. 8 ust. 1 p.p.m. w odniesieniu do krajowych przepisów wymuszających swoje zastosowanie konsekwentnie posługuje się terminem zastosowanie. Co więcej, również w uzasadnieniu rządowego projektu ustawy prawo prywatne międzynarodowe w odniesieniu do art. 9 (został uchwalony w niezmienionym kształcie jako art. 8 p.p.m.) konsekwentnie wskazywano, że krajowe przepisy wy-

${ }^{66}$ M.A. Zachariasiewicz: O potrzebie..., s. 38.

${ }^{67}$ B. Fuchs: Przepisy wymuszajace swoja właściwość w przyszłej kodyfikacji prawa prywatnego międzynarodowego. KPP z. 3, 2000, s. 663.

${ }^{68}$ B. Fuchs: Przepisy wymuszajace swoje zastosowanie $w$ nowej ustawie - Prawo prywatne międzynarodowe. W: Współczesne wyzwania prawa prywatnego międzynarodowego. Red. J. Poczobut. Warszawa 2013, s. 81.

${ }^{69}$ Zob. M. Czepelak: Międzynarodowe..., s. 483 i n.

${ }^{70}$ ECLI:EU:C:2016:774. 
muszające swoje zastosowanie są stosowane, podczas gdy przepisy obce podlegaja jedynie uwzględnieniu ${ }^{71}$. Dokonujac wykładni przepisu art. 8 ust. 2 p.p.m., należy sięgnać w pierwszej kolejności do dyrektyw wykładni językowej. Zgodnie z dyrektywą języka potocznego sformułowaniom zawartym w przepisach należy nadawać takie znaczenie, jakie maja one w języku potocznym, chyba że ważne względy przemawiaja za odstąpieniem od tego znaczenia. Odwołując się do słownika języka polskiego, należy wskazać, że na gruncie języka potocznego pojęciu uwzględnienia przypisuje się następujące znaczenie: „zauważać, brać pod uwagę, nie lekceważyć, liczyć się z czymś"72. Na potrzeby dokonywanej analizy uzasadnione wydaje się zestawienie znaczenia potocznego wskazanego wyżej terminu z pojęciem stosowania na gruncie języka potocznego. I tak oznacza ono: „wprowadzać coś $w$ życie; realizować coś; używać czegoś $w$ jakimś celu"r3. Zestawienie znaczenia potocznego wyżej wskazanych terminów prowadzi do wniosku, że nieuzasadnione jest przyznanie im tego samego znaczenia. Wydaje się, że biorąc pod uwagę kontekst znaczeniowy wskazanych terminów, intuicyjnie zastosowanie opisuje dalej idąca formę aktywności w porównaniu z uwzględnianiem. Należy przy tym mieć na uwadze, że terminy te $\mathrm{w}$ toku prowadzonej analizy trzeba odnosić właśnie do aktywności podejmowanej przez organ stosujący prawo. Wynika z tego, że nie można traktować ich w sposób tożsamy na gruncie języka potocznego. Ponadto w ramach wykładni językowej analizowanego przepisu należy pamiętać o zakazie wykładni synonimicznej, polegającym na tym, że różnym zwrotom nie należy nadawać tego samego znaczenia. W odniesieniu do analizowanych terminów z uwagi na wyraźne ich rozróżnienie przez ustawodawcę, tym bardziej uzasadnione wydaje się nadawanie im odmiennego znaczenia. Zwrócić należy również uwagę, że z funkcjonalnego punktu widzenia każdy z nich odnoszony jest do zupełnie innej grupy przepisów, zastosowanie - do krajowych przepisów wymuszających swoje zastosowanie, które obowiązuja $\mathrm{w}$ ramach polskiego porządku prawnego, natomiast uwzględnienie - do obcych przepisów wymuszajacych swoje zastosowanie, które nie wchodzą w skład polskiego porządku prawnego. Mając powyższe na uwadze, przy dokonywaniu wykładni przepisu art. 8 ust. 2 p.p.m. należy dojść do wniosku, że uwzględnienie obcych przepisów wymuszających swoje za-

${ }^{71}$ Uzasadnienie do rządowego projektu ustawy prawo prywatne międzynarodowe dostępnego na stronie internetowej Sejmu RP, s. 12, http://orka.sejm.gov.pl/Druki6ka. nsf/0/41AC5CA590174CA4C12574F80042042F/\$file/1277-uzasadnienie.doc [dostęp: 15.01.2020 r.].

${ }^{72}$ B. Dunaj: Stownik wspótczesnego języka polskiego. ŚŹ. T. 5. Kraków 2002, s. 151 .

${ }^{73}$ Ibidem, s. 379. 
stosowanie pochodzących z państwa trzeciego nie jest tożsame $\mathrm{z}$ ich stosowaniem $^{74}$. Dlatego też należy skłonić się ku poglądowi, zgodnie z którym uwzględnienie obcych przepisów wymuszających swoje zastosowanie na gruncie przepisu art. 8 ust. 2 p.p.m. nie może być utożsamiane z ich stosowaniem, jako podstawy prawnej rozstrzygnięcia. Skoro przepis art. 8 ust. 2 p.p.m. nie pozwala na stosowanie obcych przepisów wymuszajacych swoje zastosowanie, ale jedynie na ich uwzględnienie, to nie sposób przyjąć, że zawiera on normę kolizyjną $\mathrm{II}^{\circ}$ rozstrzygająca o możliwości zastosowania jednostronnej normy kolizyjnej $\mathrm{I}^{\mathrm{o}}$ zintegrowanej z norma merytoryczna. Norma kolizyjna $\mathrm{II}^{\mathrm{o}}$ poza zakresem, obejmujacym wskazanie norm kolizyjnych $\mathrm{I}^{\circ}$, między którymi rozstrzygana jest kolizja, zawiera $\mathrm{w}$ dyspozycji nakaz zastosowania określonego prawa (przepisu). Podczas gdy art. 8 ust. 2 p.p.m. pozwala jedynie na uwzględnienie obcych przepisów wymuszajacych swoje zastosowanie. Nie zawiera on elementu charakterystycznego dla struktury normy kolizyjnej $\mathrm{II}^{\circ} \mathrm{w}$ postaci nakazu zastosowania określonego prawa (przepisu).

Rozważenia wymaga, czy możliwe jest zrekonstruowanie normy kolizyjnej $\mathrm{II}^{\circ}$ na podstawie art. 30 rozporządzenia spadkowego. Zgodnie z tym przepisem, w przypadku, gdy prawo państwa, w którym znajdują się niektóre nieruchomości, przedsiębiorstwa lub inne szczególne kategorie składników majątku, zawiera szczególne przepisy nakładające z przyczyn ekonomicznych, rodzinnych lub społecznych, ograniczenia dotyczace dziedziczenia lub wpływajace na dziedziczenie w odniesieniu do tych składników majątku, maja one zastosowanie bez względu na prawo właściwe dla dziedziczenia. Szczególne przepisy, o których mowa $\mathrm{w}$ przywołanym przepisie, maja zastosowanie do dziedziczenia w takim zakresie, w jakim na mocy prawa tego państwa maja one zastosowanie bez względu na prawo właściwe dla dziedziczenia. Zakres normy zawartej $\mathrm{w}$ art. 30 rozporzadzenia spadkowego obejmuje przepisy stosowane w systemie prawnym, w którym obowiązuja, niezależnie od tego, jakie prawo jest właściwe dla danej sytuacji życiowej ${ }^{75}$. O stosowaniu wskazanych przepisów decydują zawarte $\mathrm{w}$ nich jednostronne normy kolizyjne wyznaczające zakres ich zastosowania. Natomiast przepis art. 30 rozporządzenia spadkowego zawiera nakaz zastosowania wskazanych szczególnych kategorii przepisów o imperatywnym charakterze. W ustępie 54

${ }^{74}$ Zob. K. Lipstein: Inherent Limitations in Statutes and The Conflict of Laws. W: Contemporary Problems in The Conflict of Laws. Essays in Honour of John Humphrey Carlile Morris. Londyn 1978, s. 199.

${ }^{75}$ Por. M.A. Zachariasiewicz, w: Prawo prywatne międzynarodowe. Komentarz. Red. M. Pazdan. Warszawa 2018, s. 1229; A. Machnikowska, w: Unijne Rozporzadzenie spadkowe Nr 650/2012. Komentarz. Wyd. 2. Red. M. Załucki. Warszawa 2018, s. 233 . 
preambuły do rozporządzenia spadkowego wskazano wprost, że omawianym przepisom powinno zapewnić się „stosowanie”, a nie jak w przypadku Rzym I „przyznanie skuteczności”. Ponadto we wskazanym fragmencie preambuły zaznaczono, że ustanowiony wyjątek należy interpretować w sposób bardzo ścisły, przesądzajac przy tym, że: „ani normy kolizyjne poddajace nieruchomość przepisom prawa innego niż prawo właściwe dla majatku ruchomego ani przepisy przewidujace udziat obowiazkowy większy niż przewidziany prawem właściwym dla dziedziczenia na mocy (...) rozporzqdzenia nie moga być uważane za szczególne uregulowania nakładajace ograniczenia dotyczace dziedziczenia niektórych sktadników majatku lub wptywajace na ich dziedziczenie". Mając powyższe na względzie, należy zauważyć, że w drodze wskazanego przepisu rozporzadzenia spadkowego została wyraźnie dopuszczona możliwość stosowania obcych przepisów wymuszających swoje zastosowanie pochodzących z państwa trzeciego. W konsekwencji, omawiany przepis stanowi podstawę do rekonstrukcji normy kolizyjnej $\mathrm{II}^{\mathrm{o}}$ zezwalającej na stosowanie obcych przepisów wymuszajacych swoje zastosowanie. Przepis art. 30 rozporządzenia spadkowego pozwala na rekonstrukcję zakresu normy kolizyjnej, która obejmuje szczególne kategorie przepisów o charakterze bezwzględnie obowiąującym odnoszące się do szczególnych kategorii składników majątku spadkowego, jednocześnie dyspozycja omawianego przepisu zawiera nakaz zastosowania przepisów objętych jego zakresem.

\section{Podsumowanie}

Reasumując, wykładnia przepisów art. 9 ust. 3 Rzym I oraz art. 30 rozporządzenia spadkowego pozwala na zrekonstruowanie na ich podstawie norm kolizyjnych $\mathrm{II}^{\circ}$ zezwalających na stosowanie obcych przepisów wymuszających swoje zastosowanie, tj. normy merytorycznej zintegrowanej z jednostronną normą kolizyjną $\mathrm{I}^{\circ}$ wyznaczajacca zakres zastosowania wskazanej normy merytorycznej. Tym samym, o zastosowaniu zintegrowanej normy kolizyjnej $\mathrm{I}^{\circ}$ przesądza norma kolizyjna $\mathrm{II}^{\circ}$ zawarta w art. 9 ust. 1 Rzym I lub art. 30 rozporządzenia spadkowego, natomiast wskazana norma kolizyjna $I^{\circ}$ rozstrzyga o zakresie zastosowania normy merytorycznej z nią zintegrowanej, wynikającej z przepisu wymuszającego swoje zastosowanie.

Mając powyższe na uwadze, podstawa stosowania obcych przepisów wymuszających swoje zastosowanie sensu stricto jest zintegrowa- 
na z normą merytoryczna jednostronna norma kolizyjna $\mathrm{I}^{\mathrm{o}}$ stosowana $\mathrm{w}$ oparciu o normę kolizyjną $\mathrm{II}^{\circ}$ państwa forum zawarta w art. 9 ust. 3 Rzym I albo art. 30 rozporządzenia spadkowego. W zakresie nie objętym wskazanymi przepisami brak jest normy kolizyjnej $\mathrm{II}^{\circ}$ pozwalającej na stosowanie obcych przepisów wymuszających swoje zastosowanie sensu stricto. Oznacza to, że pozostałe przepisy wymuszajace swoje zastosowanie sensu stricto mogą być jedynie uwzględniane jako element stanu faktycznego zgodnie z art. 8 ust. 2 p.p.m., a nie stosowane, jako podstawa prawna rozstrzygnięcia. 
